\title{
EFFECT OF MUNICIPAL SEWAGE EFFLUENT ON SOIL AND CROPS CULTIVATED ON A HYPER-ARID ZONE SANDY SOIL
}

\author{
R. B. Voegborlo ${ }^{1}$ and M. O. Abdulkabir ${ }^{2}$ \\ ${ }^{1}$ Chemistry Department, Kwame Nkrumah University of Science \& Technology, Kumasi, Ghana \\ ${ }^{2}$ Environmental Sciences Department, Faculty of Engineering \& Technology, \\ University of Sebha, Brack-Alshati, Libya
}

\begin{abstract}
The effects of sewage effluent from Sebha Municipal Area in the Fezzan region of Libya on certain physicochemical properties of a hyper-arid zone sandy soil and growth of two plants were studied. The soil had been treated daily with 25, 50, 75 and 100\% effluent; and barley (Hordeum vulgare) and broad beans (Vicia faba) had been grown on the soils in pots. Soil samples were analysed for water-soluble salts, electrical conductivity, cation exchange capacity, $\mathrm{pH}$, organic matter, sodium, potassium and phosphorus. At all the concentrations of effluent used there was a significant increase in all the soil properties tested. The greatest changes were observed with $100 \%$ effluent. The soils supporting crops were found to have lower concentrations of nutrients than those without crops. There was an increase in dry matter production by plants grown in effluent treated soils. The results indicate that sewage effluent could be considered as one of the possible and alternate sources of irrigation water.
\end{abstract}

Keywords: municipal sewage effluent, irrigation, hyper-arid zone, sandy soil

\section{INTRODUCTION}

The application of sewage sludge and effluents on agricultural soils is increasingly receiving attention (Harivandi, 1982; Jiries, 2001; Arar, 1991). This has become an important routine of urban and industrial wastes disposal programmes with substantial ecological and recreational benefits (Day et al., 1972; Gorden et al., 1975; D'Itri et al., 1981; FAO, 1992; Strauss, 2000).

The use of sewage water for irrigation is a positive way to dispose off sewage. Such large volumes of water in a country with persistent droughts and unreliable rainfall can be of great agronomic and economic importance. Irrigation with sewage water can increase water supply for alternative use. The utilization of sewage water also contributes to cleaning of the environment, as the water is not discharged into water bodies that could otherwise get polluted. In addition to these direct economic benefits that conserve natural resources, this water contains a lot of nutrients that can serve as an alternative source to chemical fertilizers which are expensive (FAO, 1992; Avemelech, 1993). It has been estimated that typical wastewater from domestic sources could supply all the nutrients that are normally required for agricultural crop production (FAO, 1992).

Many workers have monitored the effects of sewage effluents on the chemical properties of soils, the germination of seeds and growth and development of plants (Bole and Bell, 1978; Feigin et al., 1979; El-Nennah and El-Kobbia, 1983; Hillel et al., 1986; Siebe, 1995; Emongor et al., 2005; Aganga et al., 2005). Other workers have reported significant effects of various industrial and sewage effluents on the chemical composition of different soils and the germination of seeds and growth of different crop plants (Ajmal and Khan, 1984; Ajmal et al., 1984; Aganga et al., 2005). The suitability of soils for receiving waste waters without deterioration varies widely, depending on certain properties of the soil such as their infiltration capacity, permeability, cation and anion exchange capacities, water holding capacity and texture (Schneider and Erickson, 1972; Brady and Weil, 1999). In hyper-arid Fezzan region of Libya (UNESCO, 1977) in the central sahara desert where groundwater is the only natural water resource available, increasing water demand has necessitated reusing treated municipal waste water for irrigation of sandy soils. This study was therefore designed to assess the effects of sewage effluent on a hyper-arid soil and two cultivated crops in the central sahara. 


\section{MATERIALS AND METHODS}

\section{Sewage Effluent and Soil Characterisation}

The sewage effluent used for the study was obtained from the Sebha Municipal Waste Treatment Plant located at the outskirts of Sebha city. The wastewater resources originate from mainly household activities, as very limited industrial activities exist in the municipality. The effluent was analysed for some physicochemical properties based on standard methods (Standard Methods for the Examination of Water and Wastewater, 1975). Table 1 presents the results of the parameters tested.

The soil used in this study was collected by gathering samples from the surface layer $(0-15 \mathrm{~cm})$ of uncultivated fields around the treatment plant. The soil was air-dried and passed through a $2-\mathrm{mm}$ plastic sieve to remove rocks and other large particles. A representative sub-sample of the soil was used for characterisation and preparation for a pot-culture experiment. Soil $\mathrm{pH}$ and electrical conductivity were measured in deionised water using a $1: 1(\mathrm{w}: \mathrm{v})$ soil:solution ratio and $\mathrm{CaCO}_{3}$ content was measured by the standard $\mathrm{HCl}$ neutralisation test (Jackson, 1974). Organic matter in the soils was determined by a Walkley-Black procedure (Nelson and Sommers, 1982). Soil texture was determined by the pipette method (Kilmer and Alexander, 1949), and cation exchange capacity (CEC) was determined following the method of Rhoades (1982). Sodium and potassium concentrations were determined by flame photometry after extracting with $1 \mathrm{M}$ ammonium acetate solution $(\mathrm{pH}=7)$. Some physico-chemical properties of the soil are presented in Table 2.

\section{Pot-culture experiment}

Pot experiments were conducted to assess the effect of the sewage effluent on the chemical changes in the soil with diluted and undiluted effluent after cultivation and without cultivation. Two kilograms of air-dried soil was put into each of 30 pots, $18 \mathrm{~cm}$ in diameter and $16 \mathrm{~cm}$ high. The soils were irrigated daily with $100 \mathrm{ml}$ of $25 \%, 50 \%, 75 \%$ and $100 \%$ treated sewage effluent. Control pots were similarly irrigated with distilled water. Seeds of broad beans (Vicia faba) and barley (Hordeum vulgare) were sown in each pot. After germination, the pots were thinned out to three seedlings per pot. One set of pots was left without plants for each concentration to monitor the effect of irrigation on soil alone. The experiment was a completely randomised design with three replications.

The plants were harvested at soil level 50 days after planting, and the shoots were washed with deionised water, dried in an oven at $70^{\circ} \mathrm{C}$ for $24 \mathrm{~h}$ and weighed for dry matter determination. The dried samples were ground and digested in a mixture of nitric and perchloric acids. The soil from the pots were air-dried and analysed for various parameters.

\section{Statistical treatment of data}

Analysis of variance (ANOVA) and Duncans multiple range test (LSD) were carried out on soil properties in the treated soils to test for significant variation between the treatment pots. Data on dry matter production was analysed by t-test. All the statistical tests were carried out using the Statgraphics Plus Statistical Package version 6.0.

\section{RESULTS AND DISCUSSION}

\section{Effects of effluent treatment on pot soils}

Some characteristics of the effluent and soil used in this study are presented in Tables 1 and 2 respectively. 


\begin{tabular}{lr}
\hline $\mathrm{pH}$ & 6.93 \\
$\mathrm{TDS}\left(\mathrm{mg} \mathrm{l}^{-1}\right)$ & 858 \\
$\mathrm{Mg}^{2+}\left(\mathrm{mg} \mathrm{l}^{-1}\right)$ & 18.24 \\
$\mathrm{Ca}^{2+}\left(\mathrm{mg} \mathrm{l}^{-1}\right)$ & 51.2 \\
$\mathrm{Cl}^{-}\left(\mathrm{mg} \mathrm{l}^{-1}\right)$ & 205.3 \\
$\mathrm{SO}_{4}^{2-}\left(\mathrm{mg} \mathrm{l}^{-1}\right)$ & 1.60 \\
$\mathrm{EC}\left(\mathrm{mmhos} \mathrm{cm}^{-1}\right)$ & 2.5 \\
Organic P $\left(\mathrm{mg} \mathrm{l}^{-1}\right)$ & 1.45 \\
Total P $\left(\mathrm{mg} \mathrm{l}^{-1}\right)$ & 2.02 \\
Hydrolyzable P $\left(\mathrm{mg} \mathrm{l}^{-1}\right)$ & 1.05 \\
\hline
\end{tabular}

Table 2: Some physico-chemical properties of the experimental soil

\begin{tabular}{lr}
\hline \multicolumn{1}{c}{ Soil Texture } & Sandy \\
\hline $\mathrm{pH}\left(1: 1 \mathrm{H}_{2} \mathrm{O}\right)$ & 8.13 \\
Organic Matter (\%) & 0.19 \\
${\text { CEC meq } 100 \mathrm{~g}^{-1}}_{\mathrm{EC} \mathrm{mhos} \mathrm{cm}}^{-1}$ & 2.38 \\
$\mathrm{CaCO} 3(\%)$ & 0.99 \\
Clay ( \% ) & 0.26 \\
Silt (\%) & 3.2 \\
Sand (\%) & 2.69 \\
\hline
\end{tabular}

The effluent was colourless and had low Biological Oxygen Demand (BOD). The effects of the different dilutions $(0,25,50,75$ and $100 \%)$ of the effluent on certain chemical properties of the pot soils after 50 days are shown in Table 3. The results of the study indicated that the application of effluent to soil had significant effects on all parameters tested. There was a significant increase in the water soluble salts $(\mathrm{P}<0.001), \mathrm{pH}(\mathrm{P}<0.001)$, electrical conductivity $(\mathrm{P}<0.001)$, cation exchange capacity $(\mathrm{P}<0.001)$, organic matter $(\mathrm{P}<0.001)$, ammoniun acetate $(\mathrm{pH}=7)$ extractable sodium and potassium $(\mathrm{P}<0.001)$ The greatest changes in the soil composition were observed when the soil was irrigated with $100 \%$ of the effluent followed by 75,50 and $25 \%$. The pot soils supporting beans and barley plants irrigated with the various effluent concentrations were also analysed and the results presented in Table 4 . The concentrations of the tested parameters increased significantly $(\mathrm{P}<0.001)$ with increasing effluent concentration, but the nutrients were lower in the soils supporting these plants as compared to the pots without plants irrigated with the same effluent concentrations 
Table 3: Effects of Different Dilutions of Sewage Effluent on Certain Properties of Pot Soils

\begin{tabular}{|c|c|c|c|c|c|c|c|c|}
\hline $\begin{array}{c}\text { Treatment } \\
\text { (\% Effluent) }\end{array}$ & $\begin{array}{c}\mathrm{PH} \\
\left(1: 1 \mathrm{H}_{2} \mathrm{O}\right)\end{array}$ & $\begin{array}{c}\mathrm{CEC} \\
\left(\text { meq } 100 \mathrm{~g}^{-1}\right)\end{array}$ & $\begin{array}{c}\text { Soluble Salts } \\
\left(\mathrm{mg} \mathrm{l}^{-1}\right)\end{array}$ & $\begin{array}{c}\mathrm{EC} \\
\left(\mathrm{mmhos} \mathrm{cm}^{-1}\right)\end{array}$ & $\begin{array}{c}\text { Organic matter } \\
(\%)\end{array}$ & $\begin{array}{l}\text { Sodium } \\
\left(\mu \mathrm{g} \mathrm{g}^{-1}\right)\end{array}$ & $\begin{array}{c}\text { Potassium } \\
\left(\mu \mathrm{g} \mathrm{g}^{-1}\right)\end{array}$ & $\begin{array}{l}\text { Total P } \\
\left(\mu \mathrm{g} \mathrm{g}^{-1}\right)\end{array}$ \\
\hline 0 & 7.83 & 2.45 & 550.4 & 0.86 & 0.188 & 168.2 & 191.1 & 93.34 \\
\hline 25 & 8.04 & 2.60 & 716.8 & 1.12 & 0.196 & 228.0 & 213.1 & 95.42 \\
\hline 50 & 8.05 & 3.14 & 787.2 & 1.23 & 0.215 & 241.8 & 207.1 & 98.59 \\
\hline 75 & 8.07 & 3.65 & 972.8 & 1.52 & 0.221 & 235.6 & 213.3 & 98.70 \\
\hline 100 & 8.07 & 3.92 & 1068.8 & 1.67 & 0.359 & 295.4 & 229.0 & 111.87 \\
\hline
\end{tabular}

Table 4: Effects of Different Dilutions of Sewage Effluent on Certain Properties of Pot Soils Supporting Different Crops

\begin{tabular}{|c|c|c|c|c|c|c|c|c|c|c|c|c|c|c|c|c|}
\hline \multirow[t]{2}{*}{$\begin{array}{c}\text { Treatment } \\
\text { (\% Effluent) }\end{array}$} & \multicolumn{2}{|c|}{$\begin{array}{c}\mathrm{pH} \\
\left(1: 1 \mathrm{H}_{2} \mathrm{O}\right)\end{array}$} & \multicolumn{2}{|c|}{$\begin{array}{c}\text { CEC } \\
\left(\text { meq } 100 \mathrm{~g}^{-1}\right)\end{array}$} & \multicolumn{2}{|c|}{$\begin{array}{c}\text { Soluble Salts } \\
\left(\mathrm{mg} \mathrm{l}^{-1}\right)\end{array}$} & \multicolumn{2}{|c|}{$\begin{array}{c}\mathrm{EC} \\
\left(\mathrm{mmhos} \mathrm{cm} \mathrm{cm}^{-1}\right)\end{array}$} & \multicolumn{2}{|c|}{$\begin{array}{c}\text { Organic matter } \\
(\%)\end{array}$} & \multicolumn{2}{|c|}{$\begin{array}{l}\text { Sodium } \\
\left(\mu \mathrm{g} \mathrm{g}^{-1}\right)\end{array}$} & \multicolumn{2}{|c|}{$\begin{array}{l}\text { Potassium } \\
\left(\mu \mathrm{g} \mathrm{g}^{-1}\right)\end{array}$} & \multicolumn{2}{|c|}{$\begin{array}{l}\text { Total P } \\
\left(\mu \mathrm{g} \mathrm{g}^{-1}\right)\end{array}$} \\
\hline & Beans & Barley & Beans & Barley & Beans & Barley & Beans & Barley & Beans & Barley & Beans & Barley & Beans & Barley & Beans & Barley \\
\hline 0 & 7.78 & 7.82 & 2.08 & 1.81 & 512.0 & 537.6 & 0.80 & 0.84 & 0.188 & 0.194 & 46.6 & 61.1 & 164.5 & 159.6 & 105.0 & 100.0 \\
\hline 25 & 7.91 & 8.03 & 2.11 & 1.88 & 582.4 & 595.2 & 0.91 & 0.93 & 0.196 & 0.208 & 94.5 & 79.4 & 173.1 & 153.9 & 115.2 & 109.6 \\
\hline 50 & 8.00 & 8.09 & 2.30 & 1.99 & 633.6 & 672.0 & 0.99 & 1.05 & 0.215 & 0.209 & 103.9 & 124.7 & 171.9 & 166.4 & 118.9 & 110.2 \\
\hline 75 & 8.02 & 8.20 & 3.11 & 2.78 & 697.6 & 755.2 & 1.09 & 1.18 & 0.237 & 0.330 & 175.7 & 157.5 & 182.4 & 178.7 & 114.6 & 111.1 \\
\hline 100 & 8.04 & 8.23 & 3.53 & 3.09 & 736.0 & 832.0 & 1.15 & 1.30 & 0.378 & 0.331 & 184.5 & 171.3 & 194.6 & 165.2 & 121.9 & 112.1 \\
\hline
\end{tabular}


These results indicate uptake of water-soluble salts and available nutrients from the effluents, through the soil by plants. Similar results have been reported by other authors (Igbounamba, 1972; Ajmal and Khan, 1984; Emongor et al., 2005).

The average dry matter production is presented in Table 5. Shoot weight was considered as a measure of dry matter production in this study. The results indicate that plants grown in effluent irrigated soil produced significantly higher $(\mathrm{P}<0.001)$ dry matter yield than in the control soil. The highest concentration of effluent treatment produced the highest dry matter per pot for both crops. Vicia faba gave significantly $(\mathrm{P}<0.001)$ higher shoot weight than Hordeum vulgare (Table 5$)$. The increase in dry matter could be attributed to the nutrients contained in the effluent.

Table 5: Comparison of Dry Matter Production by Beans and Barley Shoots

\begin{tabular}{ccc}
\hline $\begin{array}{c}\text { Treatment } \\
\text { (\% Effluent) }\end{array}$ & \multicolumn{2}{c}{ Shoot weight (g) } \\
Beans & Barley \\
\hline 0 & $0.83^{*}$ & 0.32 \\
25 & $1.11^{*}$ & 0.55 \\
50 & $1.25^{*}$ & 0.66 \\
75 & $1.79^{*}$ & 0.86 \\
100 & $2.46^{*}$ & 0.91 \\
\hline
\end{tabular}

* Indicates significantly higher value $(P<0.001)$

Data illustrating the relationship between effluent concentration and dry matter is presented in Fig. 1. The shoot of both plants showed linear increase in weight as the effluent concentration increased. For Beans, the equation was $y=0.0158 \mathrm{x}+0.6984$ with $\mathrm{r}^{2}$ of 0.8396 ; and for Barley the equation was $\mathrm{y}=0.0059 \mathrm{x}+0.3629$ with $\mathrm{r}^{2}$ of 0.9232 .

Considering the results of this study sewage effluent could be considered one of the possible and alternate sources of irrigation water. But the accumulation of heavy metals and their uptake by plants should be considered, although in this study no symptoms of toxicity have appeared on the plants within the period of investigation.

\section{REFERENCES}

Aganga, A. A., Machacha, S., Sebolai, B., Thema, T. and Marotsi, B. B. (2005). Minerals in Soils and Forages Irrigated with Secondary Treated Water in Sebele, Botswana. J. Applied Sci 5, 155-161

Ajmal, M. and Khan, A. U. (1984). Effects of Brewery Effluent on Agricultural Soil and Crop Plants. Environ. Pollut., Ser. A. 33, 341-351.

Ajmal, M., Khan, M. A. and Nomani, A. A. (1984). Effects of industrial dairy effluent on soil and crop plants. Environ. Pollut., Ser. A, 33, 97-106.

Arar, A. (1991). Wastewater reuse for irrigation in the near east region. Wat. Sci. Technol., 23, $2127-$ 2134

Avemelech, Y. (1993). Irrigation with Sewage Effluents: The Israeli Experience. Env. Sci. Technol, 27, 1278-1281

Bole, J. B. and Bell, R. G. (1978). Land application of municipal sewage waste water: Yield and chemical composition of forage crops. J. environ. Qual., 7, 222-6.

Brady, N. C. and Weil, R. R. (1999). The Nature and Properties of Soils (12 ${ }^{\text {th }}$ Edn), Pretence Hall International Inc. Upper Saddle River. New Jersey, USA, pp: 634

Day, A. D., Strochlein, J. L. and Tucker, T. C. (1972). Effects of treatment plant effluent on soil crops. J. Wat. Pollut. Control Fed., 44, 372. 
D'Itri, F. M., Aquirre-Martinez and Athir-Lambauri, M. (1981). Municipal Waste Water In Agriculture, Academic Press, Inc, London Ltd.

El-Nennah, M. and El-Kobbia, T. (1983). Evaluation of Cairo Sewage Effluent for Irrigation Purposes. Env. Poll., 5, 233-245.

Emongor, V. E., Khonga, E. B., Ramolemana, G. M., Marumo, K., Machacha, S. and Motsamai, T. (2005). Suitability of Treated Secondary Sewage Effluent for Irrigation of Horticultural Crops in Botswana. J. Applied Sci 5, 451-454

FAO (Food and Agriculture Organisation) (1992). Wastewater treatment and use in agriculture. FAO Irrigation Paper 47: Food and Agriculture Organisation of the United Nations, Rome, Italy.

Feigin, A., Bielorai, H., Shalhevet, J., Kipnis, T. and Dang, J. (1979). The effectiveness of some crops in removing minerals from soils irrigated with sewage effluent. Progr. Wat. Technol., 11, 151-62.

Gorden, L. D., Young, R. H. F., Stephen, L., Ekern, P. C. and Philip, C. S. (1975). Land disposal of waste water in Hawaii. J. Wat. Pollut. Control Fed., 47, 2067.

Harivandi, M. A. (1982). The Use of Effluent Water for Turfgrass Irrigation. California Turfgrass Culture, $32,3,4$.

Hillel, I. S., Arver, A., Badri, F., Eliyahu, R. and Perez, Y. (1986). Wastewater irrigation in developing countries. Health effects and technical solutions. World Bank Technical Paper No 51. United Nations Development Program Project, Management Report 6. The World Bank, Washington DC, USA.

Igbounamba, O. (1972). Exchangeable reserve potassium and other cation reserves in Agodi and Ado soils. Soil Sci., 113, 394-409

Jackson, M. L. (1974). Soil Chemical Analysis. New Delhi, Prentic-Hall of India.

Jiries, G. A. (2001). Chemical Evaluation of Treated Sewage Effluents in Karak Province and its Suitability for Irrigation Purposes. Pak J. Biol Sci., 4, 1400-1402

Kilmer, V. J. and Alexander, L. T. (1949). Methods of making mechanical analysis. Soil Sci. 68, 1524.

Nelson, D. W. and Sommers, L. E. (1982). Total carbon, organic carbon, and organic matter. In Methods of Soil Analysis. Part 2. 2nd edn, ed. A. L. Page et al., Agron. Monogr. 9. ASA and SSSA, Madison, WI, USA, pp. 539-79.

Rhoades, J. D. (1982). Cation-exchange capacity. In Methods of Soil Analysis. Part 2. 2nd edn, ed. A. L. Page et al., Agron. Monogr. 9. ASA and SSSA, Madison, WI, USA, pp. 149-58.

Schneider, I. F. and Erickson, A. E. (1972). Soil Limitations for Disposal of Municipal Waste Waters, Michigan State University Research Report No. 195, p. 54.

Siebe, C. (1995). Heavy metal availability to plants in soils irrigated with wastewater from Mexico City. In: Wastewater Management Problems in Agro-industries. Selected Preceedings of Third IAWQ International Symposium, Mexico City, Mexico.

Standard Methods for the Examination of Water and Wastewater (1975). 14th edn. New York, APHAAWWA-WPCF.

Strauss, M. (2000). Reuse of urban wastewater and human excreta. EAWAG/sandec, Duebenderf, Switzerland.

UNESCO (1977). Map of the World Distribution of Arid Lands (MAB Technical Note 7) Paris, UNESCO 54pp 